DOI: https://doi.org/10.5007/1980-3532.2016n16p95

\title{
Quando os afetos batem com os bicos nas janelas: uma entrevista corajosa
}

\author{
When the affections knock with the beaks on the windows: a bold \\ interview
}

\author{
Rodrigo de Oliveira Feitosa Vaz \\ Doutorando em Psicologia Escolar e do Desenvolvimento (USP) \\ rodrigovazpsi@gmail.com
}

Andrea Saraiva de Barros

Cauê Borges

Mestranda em Psicologia Social (PUC/SP)

deasbar@gmail.com

Estudante ativo nas ocupações das escolas entre 2015 e 2016

Entrevistado

Ana Carolina Martins Gil

cauebo1@gmail.com

Mestre em Psicologia Social - (PUC/SP)

anamartinsgil@gmail.com

Resumo: Este trabalho parte da perspectiva de que os afetos são fonte de conhecimento e que seria preciso que seus efeitos sejam avaliados (FAVRET-SAADA, 2005). Para isso, optamos por afirmar como Barros \& Passos (2009) uma política da narratividade que desse conta dos afetos que experimentamos no encontro com alguns estudantes secundaristas em São Paulo. Sendo assim, nos inspiramos também em Tedesco, Sade \& Caliman (2013) que, apoiados nos estudos da pragmática, afirmam a importância da montagem da entrevista como experiência compartilhada entre entrevistador e entrevistado (s), requerendo que a escuta e o olhar se ampliem, sigam para além do puro conteúdo da experiência vivida, do vivido da experiência relatado na entrevista, e incluam seu aspecto genético, a dimensão processual da experiência, apreendida em suas variações. Seguindo essa linha, nossa escolha ético-estético-política fora de publicar na íntegra a entrevista realizada com o ex-estudante secundarista Cauê Borges, que participou nas ocupações estudantis nos anos de 2015 e 2016 na cidade de São Paulo. A entrevista busca aqui ser expressão viva em ato das resistências políticas contemporâneas.

Palavras-chave: Afetos. Estudantes. Ocupações. Coragem. Modos de resistência.

Abstract: This paper starts from the perspective that affections are a source of knowledge and that their effects must be evaluated (FAVRET-SAADA, 2005). For this, we chose to affirm as Barros \& Passos (2009) a policy of narrativity that accounts for the affects we experienced in the encounter with some high school students in São Paulo. We are also inspired by Tedesco, Sade \& Caliman (2013) who, based on pragmatic studies, affirm the importance of assembling the interview as a shared experience between interviewer and interviewee (s), requiring that listening and looking broaden, go beyond the pure content of the lived experience, the experience lived in the interview, and include its genetic aspect, the procedural dimension of the experience, understood in its variations. Following this line, our ethicalaesthetic-political choice aside from fully publishing the interview conducted with the former high school student Cauê Borges, who participated in student occupations in the years 2015 and 2016 in the city of São Paulo. The interview seeks here to be a living expression in the act of contemporary political resistance.

Keywords: Affections. Students. Occupations. Courage. Ways of resistance.

Originais recebidos em: 21/09/2017

Aceito para publicação em: 18/04/2018

\section{$\Theta \Theta \Theta \Theta$}

Este trabalho está licenciado sob uma Licença Creative Commons Atribuição-Uso NãoComercial-Vedada a criação de obras derivadas 3.0 Unported Licens

Revista Em Debate (UFSC), Florianópolis, volume 16, p. 95-115, 2016. ISSNe 1980-3532 
"Ao homem faz bem desexplicar, tanto quanto escurecer acende os vagalumes".

(Manoel de Barros)

"Ah, sim! Mas só existe coragem fisica, a coragem é sempre um corpo corajoso". (Michel Foucault.) 
Entrevistadores - A gente está cursando uma disciplina do Programa de PósGraduação de Psicologia Social da PUC-SP que chama Rebeliões da Infância ${ }^{l}$ e daí a gente leu alguns textos que falavam de rebelião e movimentos de rebelião. Não nessa ideia de rebelião do senso comum como alguém que "se rebela", mas rebelião enquanto uma resistência, um movimento de coletivos e de alguém que está resistindo a alguma coisa. E daí no final dessa disciplina vai ter alguns painéis com alguns temas e um dos temas que foram levantados foram as ocupações das escolas como algo que configuraria esse movimento de rebelião que discutimos ao longo das aulas. Essa ideia do painel, ela está desde o comecinho do semestre e se deu devido às ocupações do ano passado e o movimento foi refazendo e o tema se tornou mais atual do que a gente imaginou no começo. O que a gente pensou é que você pudesse se apresentar e falar de que coletivo você faz parte, como você foi entrando nos movimentos, como foi o ano passado, e que avaliação você tem? Como foi seguindo esse ano e também falar da experiência do MalEducado, e dos outros coletivos que fez parte (Cauê compôs o Coletivo GAS; entrevistador lembra também da existência da Juventude Faísca - Anticapitalista e Revolucionária). Acho que também falar de que escola você é... As dificuldades do movimento e a relação com a repressão que este sofre. E como foi compor com as ocupações das ETECS (Escolas Técnicas) desse ano. E como estão as perspectivas agora? Dizer-nos como funciona mesmo esse levante, essa insurreição...

Cauê - Eu sou Cauê, estou estudando no $3^{\circ}$ ano agora numa ETEC de São Paulo, tenho 17 anos. No ano passado, eu e uns amigos e amigas, a gente estava querendo militar na área secundarista. E mais nove pessoas... Na verdade, no começo do ano, a gente estava querendo fazer um coletivo entre grêmio de escolas e a gente foi fazendo as reuniões e ai, tipo, as reuniões foram diminuído em março. E aí estavam tendo desavenças nesse grupo e aí juntou eu e uns amigos que estavam nesse grupo e a gente formou um grupo fechado, pequeno, autônomo e independente chamado GAS (Grupo Autônomo de Secundaristas). E a gente estava se organizando, tentando achar escolas para ajudar na formação de grêmios e aí veio a bomba da reorganização que foi quando o governador, acho que em setembro, ele anunciou que ia fazer um projeto de reorganização escolar que consistia em transformar as escolas em ciclos únicos: a gente tem escolas com

\footnotetext{
${ }^{1}$ A disciplina fora ministrada pela Prof $^{\mathrm{a}} \operatorname{Dr}^{\mathrm{a}}$ Maria Cristina Vicentin no segundo semestre de 2016, período em que a entrevista foi realizada.
} 
Ensino Fundamental e Ensino Médio, e ele queria fazer com que cada escola tivesse um ciclo só. E ai todo mundo percebeu na hora o que isso queria dizer: seriam muitos estudantes numa mesma sala, ia ficar com mais de quarenta alunos numa mesma sala, muitos estudantes teriam de ser remanejados, pais e mães teriam de levar o filho mais novo de manhã para uma escola e o mais velho para outra, isso seria um transtorno. E muitas escolas iriam fechar. Era uma clara medida de corte de gastos. E os estudantes começaram a se movimentar desde o começo, começaram a fechar a rua próxima à escola, os professores começaram a fechar a rua. Em seis de outubro (eu acho!), foi chamada uma manifestação para o MASP (Museu de Arte de São Paulo) sem nenhuma organização prévia. Foram os três estudantes lá e chamaram o evento; o evento viralizou e a gente foi para esse ato sem saber muito o que iria acontecer. Tinham mais de 500 estudantes na manifestação.

No começo de ano os estudantes e professores entraram com muita força na greve e a gente percebeu que tinha uma força esse movimento. Nós erámos próximos da galera do Mal-Educado, que já existia desde 2011, e eles que conheciam já um processo de ocupação chileno, começaram a puxar a ocupação desde o primeiro ato. Desde o primeiro ato eles foram com um panfletinho que era "se fechar, vamos ocupar!". A gente curtiu a ideia.

Entrevistadores: Quais eram as escolas que compunham?

Cauê: Então o Mal-Educado era um coletivo fechado de militantes, sendo a maioria composta de formados. Em 2011 eram secundaristas, depois não eram mais.

A gente achou interessante eles estarem puxando isso e eles começaram a convidar algumas pessoas para comporem o que seria uma "frente Mal-Educado": teria o mesmo nome, porque o coletivo já era um pouco conhecido; mas seria diferente, por ser uma frente com várias pessoas, para puxar a responsabilidade de ocupação. Nós entramos nessa frente, que tinha também um pessoal da Zona Norte. Era uma frente que não era muito grande, era pequena, de 30 ou 40 pessoas.

No movimento geral, teve o $1^{\mathrm{o}}$ ato com 500 pessoas. Em todo ato a gente define em assembleia, ao final dos atos, o que vai acontecer dali para frente. É uma prática que a gente aprendeu. E nesse ato, em assembleia, a gente decidiu marcar outro para a semana seguinte. Nós divulgamos nas páginas (das redes sociais) e nesse outro ato tinham 2000 
estudantes; também na Av. Paulista, no MASP. O $1^{\circ}$ que teve repressão, que um professor foi preso, que estudantes foram presos.

Foi um ato superanimador. Chegamos até a Praça Roosevelt, pela Avenida Nove de Julho, e fizemos uma nova assembleia na qual decidimos fazer um $3^{\circ}$ ato. Decidimos nos encontrar no Largo da Batata, encontrar os professores, e ir até a casa do Geraldo Alkmin, no Palácio dos Bandeirantes. A gente marcou esse evento que teve entre 2000 e 3000 pessoas. Tinham menos secundaristas e mais universitários e nenhum professor. Nós percebemos como a mobilização dos professores estava fraca depois daquela greve. Chegamos até o Palácio dos Bandeirantes e apanhamos muito. Teve uma repressão muito grande e, a partir daí, o movimento começou a diminuir. Os secundaristas pararam de ir às manifestações; nós estávamos perdendo muitas aulas - porque as manifestações eram de manhã - enfim, foi perdendo a mobilização.

Dentro do Mal-Educado a gente foi se dividindo em atuações, por que a gente percebeu que manifestação central não era mais o que a gente queria. A gente queria agora começar a organizar as regiões, para nas regiões poderem começar a surgir processos de ocupação.

Só que encontramos um impasse nisso. Nós tínhamos aprovado em assembleia que faríamos as manifestações descentralizadas, mas encontramos um impasse que era: as organizações que estavam compondo as manifestações não queriam construir regionalmente. A gente imaginava que era porque na manifestação central, você consegue colocar sua bandeira ali e aparecer para todo mundo. Mas a descentralizada não tem tanta força assim, além de precisar de uma construção mais demorada. Então eles decidiram não compor essa organização.

Teve uma manifestação da APEOESP (Sindicato dos Professores do Ensino Oficial do Estado de São Paulo) que as organizações que eram próximas da gente, que estavam organizando os atos que eram independentes foram para essa manifestação da APEOESP e abandonaram a nossa mobilização. Enfim, tiverem esses impassem e foi diminuindo.

Foi, então, que eu comecei a militar mais aonde eu estudava, na Zona Oeste. No ano passado, eu estudava em uma escola privada, mas era próximo da galera do Fernão Dias e do Virgílio - que é uma escola que eu estudei depois. A gente começou a organizar na Zona Oeste; fizemos uma mobilização até a diretoria de ensino Centro-Oeste - que a 
gente sabia que não ia dar em nada, mas era mais para mostrar que a gente estava tentando o diálogo e eles não estavam dando.

Nisso já tinha passado quase um mês de mobilização, manifestações, paralizações e a gente percebeu que tínhamos que mudar a tática; que não estava dando certo e tínhamos que partir para a ocupação para ver se "dava um gás" em um negócio que estava acabado.

Tinha um grupo do Mal-Educado lá em Diadema se organizando com os estudantes de lá e nós estávamos nos organizando mais com o Fernão Dias e com o André Olinto de Melo. A gente foi estudando esse caminho que a gente traçou: "a gente precisa ocupar a escola". Estudamos, estudamos, estudamos durante uma semana. E aí decidimos " 3 a feira vamos ocupar". A galera de Diadema falou que iria ocupar na $2^{\mathrm{a}}$ feira de madrugada.

Foi isso. A gente marcou e na $3^{a}$ feira fomos cedinho e ocupamos a escola. Tinham ocupado Diadema e a gente ocupou o Fernão Dias. Foi aquele dia midiático pra caramba: a mídia foi para o Fernão Dias, a polícia cercou. Foi aquela semana, $3^{\mathrm{a}}, 4^{\mathrm{a}}, 5^{\mathrm{a}} \mathrm{e}$ $6^{\mathrm{a}}$ feira, com a polícia cercando o Fernão Dias, muita mídia. A gente achou que ia ser despejado, mas no final da semana tinham 12 escolas que tinham sido ocupadas. Então a tática tinha se expandido; eles tinham aderido à tática e nós conseguimos não ser reintegrados. Nós tínhamos decidido que ficaríamos até a reintegração, mas o juiz suspendeu a reintegração por causa da força do movimento. Não foi nenhuma ação de advogado nem nada.

A partir daí o movimento começou a explodir. Em duas semanas tinham 150, 200 escolas ocupadas.

Nesse período o GAS se desfez, ele entrou para o Mal-Educado, por que a gente achou que não fazia mais sentido a gente ter um grupo pequenininho.

Entrevistadores: Aumentou o número de secundaristas no Mal-Educado?

Cauê: No Mal-Educado aumentou. Não aumentou muito, se manteve mais ou menos o mesmo, mas saiu com um pouco mais de secundaristas da luta. Mas a gente não tinha o objetivo de aumentar. O movimento tinha um caráter independente no sentido de desde o começo denunciar o que a UNES (União Nacional dos Estudantes) e a UBES (União Brasileira dos Estudantes Secundaristas) faziam em relação ao movimento, que era 
desde o primeiro ato eles tentarem negociar com o Secretário, enquanto a gente queria ficar na rua; fazendo a pressão pela rua, fazendo o Secretário descer. Eles subiram uma comissão (no $1^{\mathrm{o}}$ ato), então desde o $1^{\mathrm{o}}$ ato a gente percebeu o caráter das entidades, da UJS (União da Juventude Socialista) que quer mais negociar para tentar desmobilizar a gente do que qualquer outra coisa.

O Governo falou que já estava negociando com a UBES e para a gente mostrar que o movimento era nosso, das escolas, o caminho era fazer o comando das escolas ocupadas, que era uma assembleia geral dos estudantes para a gente conseguir ter independência em relação a essas entidades. Se as entidades estivessem ocupando uma escola, era de boa, vamos lá, mas não façam uma coisa por trás da gente. Vamos discutir juntos.

A ideia do comando era essa: dois representantes de cada escola, eleitos em assembleia dentro da escola, iam levar para essa assembleia geral o que cada escola decidisse então era uma ideia de delgados e não de representantes. Eram delegados que não iam tirar da própria cabeça, mas iam representar o que estava sendo discutido na assembleia. E eram rotativos para não garantir lideranças. E se tivesse alguma escola que a UBES estivesse ocupando e tirasse dois delegados, firmeza. Mas não discutam por trás!

Essa ideia do comando funcionou, a gente começou a tirar a política lá. Esse espaço ganhou legitimidade em relação aos estudantes e ao estado. Eles perceberam que dialogar com a UBES não ia desmobilizar o nosso movimento.

Mas logo indo para a terceira semana a gente percebeu que não estava dando tanto certo todas as ocupações, porque o governador... No começo do ano tivemos greve de 93 dias dos professores e o governador dizia que não havia greve. Diante dessas ocupações, ele não estava nem aí se nós estávamos tendo aula ou não, perdendo aula ou não. Para ele não importa. Não havia, por isso, tanta pressão política para cima dele.

Foi por isso que a gente tirou, no comando, a decisão de fazer travamentos em ruas. Se o movimento não está dando certo só dentro das escolas, a gente tem que mostrar ele para fora. Mudar de tática de novo; perceber quando a tática está acabada.

$\mathrm{Na} 2^{\mathrm{a}}$ feira, de manhãzinha, no Fernão Dias, a gente saiu e fechou o cruzamento da Av. Rebouças com a Av. Faria Lima, com cadeiras, um ato bem simbólico: as cadeiras, que são coisas de estudantes, usaram para fechar as ruas. $\mathrm{Na} 3^{\mathrm{a}}$ feira tiveram duas ou três escolas que fizeram o mesmo. Nós também fizemos. 
Entrevistador: Nessa época você ainda estava estudando na...?

Cauê: Na escola privada. Mas não estava indo mais para a escola.

$\mathrm{Na} 4^{\mathrm{a}}$ feira foi o dia que teve aquele travamento na Av. Dr. Arnaldo, três meninos foram presos nesse dia; foi o maior alvoroço. E na $5^{\text {a }}$ feira tiveram 11 travamentos descentralizados em São Paulo. $\mathrm{Na}^{\mathrm{a}}$ feira ele (o governador) revogou o decreto, disse que iria suspender a reorganização.

$\mathrm{Na} 6^{\mathrm{a}}$ feira nós fomos avaliar o que tinha sido o movimento, o que tinha sido essa resposta, por que a gente tinha conseguido e quais seriam os passos dali para frente. Se a gente ia aceitar. E uma das coisas que a gente percebeu foi qual era o impacto dos travamentos. São Paulo já é uma cidade travada, uma cidade com trânsito. Onze travamentos. Esse dia não teve um transito maior do que o normal; foi um dia até que tranquilo de trânsito na cidade. Então o que a gente percebeu, foi que teve um impacto muito mais moral em cima do governador, do que aquela coisa que nós chamamos de "parar a cidade", "parar o transporte de mercadorias", "parar o transporte do trabalhador"; não é isso o que realmente impacta. Impacta que saiam fotos de estudantes apanhando de policiais todos os dias nas capas de jornais. Isso diminuiu pra caramba a legitimidade do governador. A gente percebeu isso.

Segundo que a gente decidiu continuar com as ocupações. Na verdade, nessa reunião nós tínhamos em torno de 30 ou 40 escolas e nós achamos que devíamos ter mais escolas representadas para conseguirmos decidir; porque o movimento tinha 250 escolas ocupadas. Nós tínhamos que ter mais legitimidade para decidir e marcamos um encontro estadual, aonde foram cerca de 250 estudantes, lá em Diadema. A gente já tinha em torno de 60 ou 70 escolas - não era a maioria, mas era o maior número que a gente tinha conseguido - e nessa reunião nós decidimos manter as ocupações.

Entrevistadores: Mas eram só escolas aqui de São Paulo?

Cauê: Não, não. Tinham escolas de Campinas, era um encontro para a gente conseguir juntar escolas do estado inteiro. Nessa reunião nós decidimos manter as ocupações, por achávamos que não tínhamos ganhado de fato e que quando a gente está numa luta... Por exemplo, em São Paulo, em 2013, quando a gente barrou a tarifa; quando o governador, o Estado, cede a alguma coisa mínima que a gente está pedindo é porque ele está com medo de que a gente consiga mais coisas. E a gente tinha esse anseio. A Revista Em Debate (UFSC), Florianópolis, volume 16, p. 95-115, 2016. ISSNe 1980-3532 
gente conseguiu barrar a reorganização, mas temos uma mobilização de 250 escolas ocupadas, nós nunca conseguimos uma coisa dessas e vai ser muito difícil de conseguir de novo. Então vamos aproveitar isso. Era a primeira vez que a gente conseguia fazer um político, a primeira vez que muita gente se organizava e nós erramos bastante. A constituição do comando, a forma como nós fizemos tem muitos acertos, a gente conseguiu fazer uma organização com caráter representativo, mas tivemos falhas também.

Entrevistadores: E o que vocês avaliam como falhas?

Cauê: Não tinha uma representatividade grande nas 250 escolas, por que eram apenas 30 ou 40 escolas que compunham. Isso, além de limites do movimento que eram dinheiro e tempo dos estudantes para conseguirem ir até a reunião; também para a gente conseguir divulgar e chegar até as escolas mais afastadas. Era difícil isso. E disposição também. Essas eram algumas das questões. Também não teve uma rotatividade dentro das próprias escolas para ir até a reunião, então as pessoas que estavam no comando... aquilo quase se tornou um coletivo e não tanto uma representação mesmo. O que as pessoas diziam no comando, não era o que estava sendo dito dentro das escolas e isso causava um descompasso. Tanto que quando decidimos manter as ocupações, as escolas começaram a desocupar. Então isso mostrou que nós não estávamos em contato com o movimento real.

As maiores adversidades foram essas; a gente se burocratizou. $\mathrm{O}$ movimento foi decaindo. Quando decidiu desocupar, nós não conseguimos desocupar com um ato grande, porque o comando tinha perdido já a legitimidade para tirar alguma coisa. A gente votou, na última reunião que a gente fez enquanto estava ocupado, que o que mais vai garantir as conquistas que tivemos, não é a manutenção das ocupações - manter as ocupações até o fim do mundo não vai servir para nada - e nem contatar advogados, ou a defensoria pública, para assegurar as nossas conquistas. Isso não ia trazer o reconhecimento das nossas conquistas. O que iria manter as nossas conquistas era a nossa organização. Como a gente tinha avaliado? As manifestações não eram mais a tática, as ocupações também não eram mais a tática daquele momento. Então a gente decidiu desocupar, mantendo a luta, é claro. Mas o importante para este ano era nos organizarmos nas escolas. Mas nesse processo de "acabou a ocupação", vamos nos 
reorganizar, vamos agora pensar como é que vão ser os (ganhos? 22m49s), essas coisas... Vem o aumento da tarifa e o comando se reorganiza em cima disso, da tarifa, começa a ir aos atos e a gente não consegue se organizar em cima da nossa pauta. Em todos os atos, a galera ia presa, apanhava, era desmoralizada.

Entrevistadores: Isso foi em janeiro (de 2016), não é?!

Cauê: Sim, em janeiro. Acaba a tarifa e a gente volta às aulas sem ter férias nenhuma, não tivemos tempo para pensar a volta às aulas. Eu fui para o Colégio Estadual Virgílio, que é um colégio no Butantã e nós voltamos às aulas com o indicativo de começar a construir grêmios independentes nas escolas.

Entrevistadores: Foi uma escolha sua ir para uma Escola Estadual?

Cauê: Eu queria há muito tempo estudar em uma escola estadual. Desde o $1^{\circ}$ ano. A luta histórica no Estado de São dos secundaristas é que os diretores são muito truculentos, uma direção muito truculenta que não é eleita pelos alunos, mas por uma escolha do governador. Ou é cargo (indicativo?) ou é concurso público.

Eu fui para o Rio Grande do Sul agora que está tendo ocupação e lá os diretores são eleitos pelos alunos. Então as direções estão apoiando as ocupações, coisa que nós não tínhamos aqui. Aqui em São Paulo temos as direções muito truculentas e não podíamos criar grêmios, porque a diretora definia "você pode ser do grêmio", "você não". Então nós não tínhamos formação de grêmios; os grêmios que eram formados eram grêmios que não conseguiam agir dentro das escolas. Ou era um grêmio mais de luta que era reprimido na hora.

Depois das ocupações o novo Secretário disse que faria 5.000 grêmios em São Paulo porque são 5.000 escolas. Num dia só ele faria uma eleição e também ia fazer um concurso público, com 1.600 vagas nesse concurso público; ou seja, ia trocar as direções, as direções não seriam mais truculentas e formaria grêmios dentro das escolas. A gente tomou um susto! Avaliamos no comando, "mas por que será que ele está fazendo isso? ". E a nossa avaliação é que eles perceberam que os estudantes vão se organizar este ano e o mais importante para eles é que a gente não se organize, mas que eles organizem a gente. Que eles consigam levar para perto deles a nossa organização e saber o que estamos fazendo.

Revista Em Debate (UFSC), Florianópolis, volume 16, p. 95-115, 2016. ISSNe 1980-3532 
Outra coisa é que as direções truculentas não serviam mais para eles. O que eles queriam agora e que vai acontecer - porque no concurso público não vai cair uma coisa militar, vai cair Paulo Freire, uma educação mais libertária. Quando a gente resolve fazer um processo de ocupação, as escolas com diretores mais libertários eram aonde não tinha greve, não tinha ocupação. Porque você vai fazer algo que bate com o Estado, mas a figura do Estado na sua escola é uma pessoa que parece que está ali ao seu favor e isso inibe a mobilização. Também é uma forma de você minar o pessoal mais radicalizado de cada escola, trazer pra perto da direção, falar "não, façam uma petição.", "Vamos ali conversar com o Secretário.", "Não é bem assim.".

Começou o ano e nós boicotamos essas eleições. Na minha escola fizemos uma assembleia geral para decidir como seria o grêmio, decidir se a gente iria ter chapas ou não, se teríamos eleição ou não. Decidimos por não ter, criamos um grêmio livre. Eu saí da escola, porque consegui entrar em uma escola técnica, que é a ETEC São Paulo, e chegando lá, começamos uma luta por merendas. Porque não tem merenda em escola técnica nenhuma. O que a escola dá é bolacha e suco. As pessoas ficam 8 horas na escola, fazendo o integrado, e não tem.

Fizemos duas manifestações e na $2^{\mathrm{a}}$ manifestação nós descemos para o Centro Paula Souza e ocupamos o Centro Paula Souza. Aí tem todo o processo de luta deste ano. Não sei se eu falo do processo de luta deste ano, meio por cima assim.

Entrevistadores: Achamos bastante interessante, pode falar sim.

Cauê: Primeiro que estudante de Escola Técnica é diferente de estudante de Escola Estadual. Tem uma diferença na base que é que a galera da escola técnica, o ensino da Escola Técnica é um pouco melhor, menos precário do que na Escola Estadual. Os espaços das Escolas Técnicas são mais desenvolvidos, com mais áreas abertas, é mais novo o ensino - eu acredito que seja mais novo. O salário dos professores é melhor do que na Escola Estadual. Ali tem um plano melhor para o estudante. Então, nas Escolas Estaduais, a galera era muito radicalizada; se a polícia fizesse alguma coisa, a galera já radicalizava. Na Escola Técnica era diferente, o pessoal mais recuado, querendo fazer as coisas mais dentro da Lei, querendo fazer petição. Quem pulou, realmente, o muro do Centro Paula Souza foram os estudantes de Escolas Estaduais do movimento do ano 
passado. Os estudantes das Escolas Técnicas foram a reboque, foram depois que já tinham pulado; aí pularam. Isso mostra um pouco a diferença.

Entrevistadores: O que você avalia que cause essa diferença?

Cauê: Acho que é o ensino mesmo, é o contato com o ensino. E nas Escolas Técnicas também tem eleição para diretor, então já existe uma introjeção nesse meio que parece democrático.

Entrevistadores: Como era estudar em uma escola... Você faz um caminho meio às avessas: veio de uma escola que era privada, foi para uma Escola Estadual e agora está numa Escola Técnica. Nesse ano que você estava na Escola Privada, um momento, inclusive, que você conta que parou de estudar, foi se envolver com o movimento. Como foi tudo isso?

Cauê: Eu militei no Movimento Passe Livre - MPL quando eu estava no $9^{\circ}$ ano. Foi um momento que eu já não gostava de estudar em Escola Particular de jeito nenhum e eu queria sair pra ETESP (Escola Técnica Estadual de São Paulo), desde o $9^{\circ}$ ano, mas eu não conseguia, porque meus pais não deixavam. Eu tinha contato com os estudantes. A minha escola - a escola privada - nunca era a "minha escola", nunca tive sentimento de pertencimento nenhum, ia para a aula só para cumprir minha matéria. Acho que o processo de ocupação foi mais desenvolveu o pensamento dos meus pais que perceberam que é muito melhor para eu estar numa Escola Pública do que numa Escola Privada. Mas em mim, acho que não mudou muito a relação com a Escola Pública; eu já queria há um tempo. Um processo de ocupação amadurece todo mundo. Todo mundo sai com outra cabeça.

Entrevistadores: E o que foi a mudança que você sentiu?

Cauê: Amadurecimento. No jeito de se portar, de falar, ter que lidar com a responsabilidade. Naquela primeira semana no Fernão Dias, tudo o que a gente decidisse em assembleia ia ter um respaldo do movimento geral. A gente não estava aguentando mais ficar lá no último dia. Eram quatro dias sem poder sair do mesmo espaço, com tensão, com polícia do lado de fora, você não poder ver seus pais. Tudo 
muito tenso e você tinham que aguentar por causa do movimento. Era uma pressão muito grande; e quando você sente essa pressão, você sai outra pessoa. Encara o mundo de outro jeito. Tudo o que você falasse, ia ter respaldo (acho que quis dizer repercussão) na mídia.

Entrevistadores: Como você chegou ao MPL? Com 14 anos?

Cauê: 14 anos. Foi em 2013. Em junho tiveram as mobilizações e eu queria me aproximar. Um professor (da escola privada) me apresentou. Eu fui lá para o Grajaú/Parelheiros, onde estava tendo uma luta; conheci o pessoal do MPL lá e fui me envolvendo.

Entrevistadores: Você estava falando sobre o Centro Paula Souza.

Cauê: Sim. Teve ocupação na $5^{\mathrm{a}}$ feira. $\mathrm{O}$ ato foi na $5^{\mathrm{a}}$ feira. $\mathrm{Na} 6^{\mathrm{a}}$ feira estava perigando ocupar uma escola ou outra. Na madrugada, de $6^{\mathrm{a}}$ para sábado, a galera do Fernão Dias, uma galera bem pequena de lá, quis ocupar o Fernão Dias junto com um pessoal de fora, uns punks "porra loca”. E entraram no Fernão Dias. Nós achávamos que não era certo fazer isso, que depois de um processo de ocupação do ano passado, as coisas tinham que ser feitas de outra forma. Talvez as Escolas Estaduais não tivessem que ser ocupadas, mas eles ocuparam e deu o maior enrosco. Os próprios alunos que gostaram da ocupação do ano passado ficaram conta a ocupação e $2^{\mathrm{a}}$ feira foi desocupado o Fernão Dias pelos próprios alunos. Isso mostrou para gente qual era o cenário. $\mathrm{Na}$ Escola Técnica, na $2^{\text {a }}$ feira o movimento ocupou a minha escola e ocuparam algumas outras. Todas as ocupações de Escolas Técnicas foram feitas por meio de assembleias: juntavam todos os estudantes e, se não tivesse legitimidade pelo voto, não continuava ocupada. As ocupações do ano passado não eram assim. Era um grupo que entrava na escola, tentava trazer o maior número de estudantes, mas não tinha essa assembleia; não era uma coisa democrática. Este ano não daria para ser assim, porque o Estado de São Paulo aprendeu... É um pouco confuso, porque ao mesmo tempo em que estavam acontecendo as ocupações em São Paulo, começaram as ocupações em Goiás e o momento em que o Estado de São Paulo errou, batendo em estudante com policial, o Estado de Goiás começou a terceirizar a repressão. Então eles faziam com que a comunidade escolar ficasse contra os estudantes, que não tivesse que ser a polícia, Revista Em Debate (UFSC), Florianópolis, volume 16, p. 95-115, 2016. ISSNe 1980-3532 
desmoralizava o movimento, porque a mídia mostrava como estavam desarticulados, os próprios alunos indo contra os alunos; não mostrava uma união. Isso causava pressão sobre os estudantes que estavam ocupando, isso cansava os estudantes, e dava legitimidade para polícia bater. O estado de São Paulo aprendeu isso e ia tentar fazer isso em cima da gente. Então não ia dar para fazer ocupação sem legitimidade.

O Fernão Dias mostrou que teve um amadurecimento dos estudantes, de continuar na luta. Alguns estudantes aprenderam que a tática tem certo momento, não dá para se aplicar a mesma tática em dois momentos diferentes, porque há uma conjuntura diferente, uma situação diferente. Então tem que agir de formas diferentes. Mas a gente superou isso e começou a ocupação em Escolas Técnicas e 4 Escolas Estaduais ocuparam.

Cerca de duas semanas o Centro Paula Souza foi reintegrado, o que não tinha acontecido em nenhum movimento secundarista; um espaço ser de fato reintegrado. Nós conseguimos nos manter mesmo sem esse espaço central de articulação, mas eles minaram os locais aonde podíamos fazer reuniões. A ETESP aonde eu estudo, que seria uma escola central para fazermos reuniões do comando teve as entradas barradas. A diretoria de ensino Centro-Oeste, aonde a gente ocupou para fazer as reuniões, minaram também; fecharam a entrada e nós não conseguimos trabalhar em nada lá.

Marcamos uma reunião, uma assembleia geral dos estudantes para $6^{\mathrm{a}}$ feira - como tinham 20 escolas ocupadas, havia chances das 20 irem mesmo - mas na $5^{\text {a }}$ feira a Dilma caiu, teve o impeachment, e isso fez com que ninguém estivesse prestando atenção na gente, estavam todos falando do Golpe ou não-Golpe. $\mathrm{Na} 6^{\mathrm{a}}$ feira o Alckmin decreta que não precisava de reintegração de posse para retirar estudantes, então desocupamos a Diretoria de Ensino Centro-Oeste, a ETESP, a Diretoria Norte, a Diretoria Guarulhos-Sul; as três diretorias e a ETESP.

Entrevistadores: Vocês foram praticamente obrigados a desocupar?!

Cauê: A gente foi desocupado. Eu estava na Diretoria de Ensino, às 6 horas da manhã a polícia apareceu lá, quebrou o portão, abriu, prendeu a gente. Sem mandado, sem nada. Foi no dia que tínhamos marcado a reunião. Acho que era muita clara a intenção de tentar desmobilizar a gente. Nós conseguimos, por fim, fazer a reunião, mas foi num dia 
de caos, tínhamos sido presos. Decidimos desocupar nessa reunião e tentar manter a mobilização. E agora estamos nisso, tentando recolher os cacos.

Entrevistadores: Eu fui a algumas assembleias estão acontecendo na Casa do Povo, que é um espaço de uma história, de abrigar movimentos sociais desde a década de 50 . Não sei se você conhece essa história. Fiquei pensando em como vocês conseguiram esse espaço para fazer as assembleias.

Cauê: A Casa do Povo é muito perto da ETESP. Eu conheci a Casa do Povo através do MPL, porque fazíamos reuniões do MPL lá. Depois nós começamos a fazer as reuniões do Mal-Educado lá e os estudantes começaram a conhecer e agora é um espaço que a gente utiliza.

Entrevistadores: $\mathrm{Eu}$ me lembro de que na última assembleia você ficou bastante incomodado. Fiquei curioso de saber qual foi esse incomodo dessa última assembleia. Eu que estava meio "na borda", achei que foi uma assembleia difícil, que se rodava em uma discussão.

Cauê: A gente não discutiu nada nessa assembleia.

Entrevistadores: Eu estava indo a algumas assembleias que estavam acontecendo na Casa do Povo, até porque eu componho ali na Casa do Povo com o seminário, que se chama "Seminário de Micropolíticas", que são pessoas já formadas e, inclusive, estávamos discutindo um texto de um livro que se chama "Revolução Molecular". Eu estava indo a essas assembleias, mas era sempre muito corrido. Quando eu conheci o Cauê nós mal nos apresentamos, porque era sempre em meio às assembleias e depois delas já tinha algum ato. Estava todo mundo sempre meio que em motim, então era sempre um pouco difícil. Nessa última assembleia, uma assembleia bem difícil, porque acho que estavam todos aos cacos, depois de tudo o que aconteceu. Por isso uma assembleia bem difícil.

Vou até fazer essa pergunta para você. Essa presença dos universitários no movimento secundarista: como você avalia isso? O que você acha que é ganho? O que você acha que é complicado? 
Você fala do Mal-Educado, que antes eram mais secundaristas, depois os universitários entraram. Como é isso? Como é essa organização? Porque o que eu senti da última assembleia é que os universitários queriam unificar as lutas - no sentido de que haveria ocupações na USP também - e, num determinado momento, na assembleia, os universitários tomaram a cena. Parecia mais uma assembleia dos universitários do que dos secundaristas, pois de repente tinha um universitário gritando, dizendo qual era a pauta, enquanto os secundaristas estavam com a voz extremamente abafada. Talvez já esteja dizendo sobre o seu incomodo, quando eu faço essa interpretação, mas queria ouvir de você qual foi o seu maior incomodo.

Cauê: A questão era que a gente não conseguia se organizar, não conseguia se articular no movimento secundarista deste ano e o resultado disso é a maior dificuldade de organização daqui para frente, depois do processo. Se a gente não consegue se organizar no processo de mobilização mesmo, o processo pós-mobilização é muito mais difícil, porque as pessoas estão cansadas, estão desmoralizadas. Os universitários entraram em luta no momento que em nós estávamos saindo de luta, achavam nosso espaço de organização importante e começaram a "colar". Nós não tínhamos tantas ressalvas, mas se não tínhamos nenhuma organização interna nossa, começar essa articulação com gente de fora seria muito difícil. Isso trouxe algumas implicações, porque não conseguíamos pensar no nosso movimento interno e tínhamos que pensar a articulação com os universitários que estavam na reunião. Isso dificultou um pouco o processo, mas acho que não é culpa deles. É algo também conjuntural, uma coisa nossa de não termos conseguido nos organizar no processo, de novo. Mas é importantíssima a articulação entre os secundaristas e os universitários, mas é importante quando nós conseguimos nos organizar; quando tem um espaço universitário e um espaço secundaristas mais ou menos definidos, para as coisas não se confundirem. Isso porque o movimento universitário funciona de um jeito e o secundarista funciona de outro, a gente está descobrindo as coisas. Muitos universitários já têm vários problemas que nós estamos conhecendo agora.

Entrevistadores: Você fala que é importante essa parceria desde que um não engula o outro, que um não tome o espaço enquanto o outro vai tendo sua voz abafada. Quais são suas perspectivas? Você vai falando que a ocupação não é apenas a ocupação, mas um 
horizonte de lutas. Como estão as perspectivas agora? Como é a relação com os outros Estados ou mesmo com os outros países - chegamos a falar do Uruguai, do Chile, vi alguns vídeos de que no Paraguai também houve ocupação e eles conseguiram tirar o Ministro da Educação de lá? Como é o contato de vocês com outros Estados e outros países? Vocês chegam, a saber, de notícias, chegam a ir ou se articular? Como é isso? O que você espera da Educação? Quais suas expectativas de uma educação que você almeja, até pelos caminhos que você foi fazendo? E o que você entende de participação social, política do jovem hoje em dia? *Ainda nessa linha, eu queria perguntar o que te mobilizou pessoalmente nesse processo de ir para o MPL. Você nos contou de um caminho que é objetivo e concreto: um professor que te levou, te apresentou e você foi. Mas o que foi seu nesse processo de se juntar a um movimento? Qual era a expectativa? O que mexeu com você que fez você ir?

Cauê: Bom... Perspectiva: acho que a perspectiva agora é não ter um processo de luta grande (estudantil) este ano; a não ser que tenha greve dos professores, mas acredito também que não vai ter. É de tentar manter as organizações nas escolas que já tem. Manter os estudantes organizados para fazer debates, seminários, lutas dentro das escolas, tirar diretores. Lutas internas, não uma luta geral. E fortalecer a articulação entre as escolas. Acho que esse seria o melhor resultado do movimento para se formar outro processo necessário de não ter que sair do nada, só da espontaneidade, mas ter uma organização para fazer.

A relação com outros estados e países: a gente não tem relação nenhuma. Acho que temos o mesmo problema que os universitários. Não temos uma organização interna, regional, em São Paulo, nos outros estados. É muito difícil conseguirmos nos organizarmos com os outros estados. O que consegue mais são outros coletivos que já são federalizados; por exemplo a ANEL (Aliança Nacional dos Estudantes Livres) que é uma entidade em que o PSTU (Partido Socialista dos Trabalhadores Unificado) está forte. Então eles têm ANEL em Sergipe, ANEL em outros lugares; então eles conseguem um intercâmbio. Até a ocupação do Chile, por exemplo, que tinham vários estudantes e estudantes que eram da LIT, a Linha Internacional Trotskista, que é a linha internacional que o PSTU faz parte e eles trouxeram um estudante chileno para cá, no nosso processo de ocupação, pra trocar uma ideia. Mas para além das organizações a gente não tem uma articulação entre os estudantes, mas é algo que temos vontade de 
criar. Para isso o comando de São Paulo precisa estar forte, para conseguirmos ter um contato com o comando do Rio de Janeiro. Temos que pensar, mas não temos tantas perspectivas concretas.

O que aconteceu é que uma organização lá do Rio Grande do Sul, da Federação Anarquista Gaúcha - FAG, estava acontecendo uma ocupação lá, muito forte, muito intensa. Duas semanas de luta e 170 escolas ocupadas, muito maior do que aqui. Eles tentaram contatar o pessoal do Mal-Educado para levar algum estudante lá. Eu fui lá agora, nesse último feriado, para conhecer a ocupação lá e trocar experiencias. Pensar que eles têm que desenvolver a luta deles - eu não fui lá dizer como eles tinham que fazer - mas mostrar como foi em São Paulo para que eles pudessem aprender com os nossos erros e não começarem o movimento do zero. Entender também como era a repressão em São Paulo e pensar como vai ser a repressão lá. A gente tem que tentar criar essa articulação.

Sobre a educação: eu não acredito em educação libertária. Eu não acho que a educação pode nos libertar do nosso sistema capitalista. Acho que precisamos... Estudantes de escolas estaduais, escolas públicas, se não forem formados para o mercado de trabalho, não sobrevivem, porque temos esse dado de realidade. A sociedade impõe essa realidade para gente. Nós não vamos vivem em uma comunidade para além dela. O que precisa é de uma educação que ensine o pensamento crítico, que tenha um caráter libertário - mas não vai libertar de fato, a questão é essa. Precisa ensinar de alguma forma, o ingresso ao trabalho; mas que ingresso é esse que a gente quer? Então uma educação que pense criticamente essa sociedade do trabalho e ensine, de alguma forma, mas que coloque a crítica. A diferença entre as escolas estaduais e as escolas técnicas é que os estudantes mostram um pouco isso: como é importante uma educação mais crítica. As escolas técnicas têm uma educação mais crítica, pelo pouco que eu percebi.

Entrevistadores: Por que você acha isso?

Cauê: Pela estrutura. Professores mais bem remunerados tem maior estrutura, tem uma seleção mais ou menos de quem vai entrar ou não na escola técnica, porque tem um processo de Vestibulinho para entrar e isso elimina os estudantes que tiveram pouca base. Enfim, não é tão pública como a gente queria, mas tem esse caráter. 
A educação, para mim, tem que ser crítica e tem que estimular o estudante a fazer mobilização política. Tem que mostrar que existe outro mundo aí. $\mathrm{O}$ mundo que a gente vive é este - colocar criticamente isso - e você vai ter que viver nele, mas a gente pode muda-lo; a mudança só acontece com luta.

A participação política que temos que ter é na organização revolucionária. Eu não acredito que a mudança vá vir pelo Estado; acho que a mudança vai vir "de baixo", vai vir da organização dos "de baixo", da organização política revolucionária. Tem a discussão se é preciso se organizar em partidos ou não, tem a experiencia de partidos anarquistas que mostra que um partido não é uma organização que luta apenas eleitoralmente, mas é uma organização que tem um projeto revolucionário. Enfim, tem um amplo leque de mobilizações que os estudantes podem ter e acho que temos que seguir por esse caminho.

Entrevistadores: E como você se vê? Como um autônomo, um anarquista?

Cauê: Eu tenho bastante crítica ao autonomismo que temos hoje. Ele tem um limite. Vimos na luta que se eu tenho uma luta de pauta única, ela tem um limite quanto à organização de que você vai ganhar essa luta, de alguma forma, mas e depois?! E agora? Ganhamos esta luta aqui, mas o que ela traz de avanços para a luta de classes? O que ela traz de avanço para a luta revolucionária? Ganhamos uma pauta ali, mas não quer dizer muita coisa. Os movimentos autônomos têm essa característica de serem pauta única e serem horizontais. Então você não consegue um movimento horizontal gigantesco; de fato, percebemos que não tem efetividade. Estamos discutindo isso. Eu tenho essas críticas ao autonomismo, mas também não acredito em organização clássica, soviética; é um modelo que já deu. Temos que entender os movimentos que estão acontecendo agora, os movimentos de junho, por exemplo. O que tivemos de acertos e erros. O movimento secundarista de agora: o que tivemos de acertos e erros, para a gente entender qual é o movimento da nossa época e tentar construir. Discutindo e construindo. Não sei ainda o que eu sou. A gente está indo no movimento, que está bem confuso ainda.

O que me fez né?! Eu estudava em escola privada, comecei a andar de skate - isso é uma coisa bem pessoal - comecei a ter contato com outras pessoas na rua, fora dos meus vínculos do colégio e passei a questionar “por que isso?”, qual era a diferença, por 
que tinham pessoas que estudava em uma escola que era paga e outras não. Comecei a questionar bem inconscientemente, no cotidiano, e fui procurar as respostas. Não lembro porque, mas acho que teve um dia - eu questionava isso na escola, mas questionava no sentido "ah, a galera que tem dinheiro é zoada e eu preciso aderir à cultura da galera mais precarizada.”. Então tinha que começar a falar errado, essas coisas. Muito sem saber o que fazer. Mas eu colocava os questionamentos na sala de aula. Um dia eu levantei a mão e um professor disse "O comunista vai falar!". Eu não sabia o que era "comunista", mas fui procurar, com 13 anos. Eu li o livro do Marx, "O Manifesto Comunista", não entendi nada, mas fui tentando ler. Foi quando vieram as manifestações de junho, eu fui. Fui a todas do MPL em junho e um professor percebeu que eu estava gostando e me jogou lá para o Grajaú, para conhecer o trabalho que a galera estava fazendo lá. Eu gostei. Também não entendia nada, mas só de estar ali, no MPL, já era muito louco para mim. Minha formação política foi acontecendo mais na prática. Formando-me através do trabalho diário.

Entrevistadores: Tem algo que fui percebendo, que é que você vai falando que acha interessante um pensamento crítico e avaliando o que foi erro. Queria ouvir também o que você acha que foi ganho. Teve um alastramento rápido dessas experiencias de ocupação. Como você avalia o tamanho da capilaridade que tiveram essas ocupações no Brasil ou fora do Brasil. E o que você entende como ganho?

Cauê: Nas primeiras reuniões do GAS, que a gente tinha criado, um dos objetivos que a gente tinha é que a gente queria retomar com os secundaristas, uma ideia de que secundarista é rebelde, no sentido de luta, que secundarista se revolta. O que a gente ouvia muito era "Na minha época, a gente construía a luta contra a ditadura...". E a gente retomou isso. Agora você fala secundarista, é sinônimo de "vai ter manifestação á'”. A polícia não gosta de secundaristas. Retornou um imaginário. Secundarista de luta é muito importante para a formação da próxima geração de secundaristas. E as pessoas que se formarem, vão entrar para o mercado de trabalho com um pensamento "Como é que faz para mudar as coisas? É ocupação, é movimento de rua.”. O maior ponto positivo é o imaginário das pessoas, o amadurecimento depois de um processo desses. Você perceber que só com luta você muda a vida. 
E esse processo se alastrou. Tem ocupações no Rio Grande do Sul, no Rio de Janeiro, no Ceará, Goiás, Paraguai. Isso colocou uma tática nova para a luta de classes no Brasil, tanto que agora está ocupada a Fábrica de Cultura, no Capão Redondo. A gente colocou uma tática à disposição, como o movimento de junho - que colocou a manifestação à disposição das pessoas - as pessoas usarem, da melhor forma, a ocupação, é uma tática nesse sentido.

O maior ganho é esse, além de termos conseguido barrar a organização. Mas o maior ganho, de uma luta concreta, acho que não é a pauta, de fato, mas a construção da vida das pessoas em cima disso.

\section{Referências}

BARROS, R.B.; PASSOS, E. Por uma política da narratividade. In. ESCÓSSIA, L.; KASTRUP, V.; PASSOS, E. Pistas do Método da Cartografia. Pesquisa-intervenção e produção de subjetividade. Porto Alegre: Sulina, 2009, pp.150-171.

FAVRET-SAADA, J. "Ser afetado". Trad. Paula Siqueira. Revista Cadernos de Campo, V. $13, n^{\circ} 13,2005$.

TEDESCO, S. H.; SADE, C.; CALIMAN, L. V. A entrevista na pesquisa cartográfica: a experiência do dizer. In: Fractal: Revista de Psicologia, Niterói, v. 25, n. 2, p. 299-322, maio/ago, 2013. 